\title{
VEGETATIONAL HISTORY OF YELLOWSTONE PARK AS DETERMINED BY POLLEN ANALYSIS
}

\author{
George C. Frison \\ Jane M. Beiswenger \\ Department of Anthropology \\ University of Wyoming
}

\section{Objectives}

The purpose of this project was to interpret the vegetational history of the Yellowstone Park area by the analysis of pollen contained in sediment cores from four locations in Yellowstone Lake. The cores, collected by Dr. Robert Smith of the University of Utah, were from the north central portion, the west thumb area, the south arm and the southeast arm of the lake. The cores were to be compared to determine pollen variations within the lake. Differences between a small pond and a large lake basin in reflecting climatic change were to be studied by comparing the results with pollen counts from Fifteen Foot Lagoon (Baker, 1976).

\section{Procedures}

As of December 8, 1978, seventy-eight samples from the four cores have been prepared, using standard procedures (Faegri and Iverson, 1950). Sixty-three samples have been counted and the pollen percentages determined. Chi square tests of homogenity were used to determine the similarity in pollen counts for samples of the same age from different cores. Sedimentation rates, available for three of the four cores (Shero, 1977), were used to determine sample age.

$\underline{\text { Results }}$

Results for the most abundant pollen types (fig. 1 and table l) show that pollen percentages have remained relatively stable for the past 1,500 years. Samples from the north central portion of the lake, dating to 3,700 years BP, also show similar pollen percentages. Sediment mixing is not a likely cause for the similarity in pollen percentages. Dredge samples collected near the Yellowstone Lake coring sites contain varves indicating very little or no mixing after the time of deposition (Shero, 1977).

The pollen profiles indicate a landscape dominated by pine, including Pinus albicaulis and Pinus contorta, with lesser amounts of spruce and fir. Pollen counts also indicate the presence of juniper, poplar, douglas-fir, and birch. Sagebrush pollen averages 11 percent of the total and pollen of the Goosefoot family (Chenopodiaceae) averages 2-3 percent. Table 1 includes an overall average for each category and an average excluding three samples from 14601484 BP. These three samples differ from the others in showing less pine and more sagebrush. This indicates that conditions were slightly warmer and drier during this span of time. The overall percentages of spruce and fir are 
higher in the core from the southeastern arm of the lake. This part of the lake is the closest to the spruce-fir vegetation zone in the Absaroka mountains (Despain, 1973). Pollen percentages indicate that the spruce-fir vegetation type has existed in the southeastern portion of the park for at least 1,500 years.

These results closely correlate with the core from Fifteen Foot Lagoon, which has pollen percentages most similar to the core from southeastern arm of Yellowstone Lake. Pollen counts from the smaller body of water ( $F$ ifteen Foot Lagoon) have a higher frequency of rare pollen types than do those from larger Yellowstone Lake. This is consistent with Tauber's (1967) discussion of smaller lakes receiving a more local pollen rain and larger lakes receiving a more regional one.

Chi square homogenity tests ( Mos imann, 1965) show seven out of thirteen pollen counts for samples of the same age from the southeast and south arms of the lake to differ significantly at the $0.05 \%$ level. Three out of twelve samples differ significantly $(0.05 \%$ level) between the core from the south arm and the core from the north central portion of the lake, while five out of twelve samples differ significantly $(0.05 \%$ level) between the core from the southeast arm and the core from the north central portion of the lake. Major differences were in the values for spruce, sagebrush and sedges. Higher spruce percentages in samples from the southeastern arm, fluctuations in the abundance of sedges growing near the lake shore, and changes in wind patterns may be contributing factors. Tests will conconducted later to determine if these differences could be ecologically significant. The high percentages of pine pollen (averaging 77\%) in this area may accentuate the differences in less abundant types.

The final stages of this research project will include determination of the relative abundances of Pinus albicaulis and Pinus contorta in samples of the same age from different cores, and construction of a pollen profile for the west thumb area of Yellowstone Lake. Completed tables of pollen counts, percentages and chi square results will be included and discussed in more detail in the final report of this study to be submitted in January, 1979.

\section{Conclusions}

Despite some differences in pollen counts from one part of Yellowstone Lake to another, the pollen profile from each core reflects a picture of climatic stability for the past 4,000 years in the Yellowstone Park area. Minor fluctuations in percentages occur but no major change in vegetation or climate is indicated. The pollen profile from Fifteen Foot Lagoon shows a similar pattern. Thus the analysis of one sediment core from any of the Yellowstone Lake sampling sites or from Fifteen Foot Lagoon would provide a reasonably accurate record of climatic change in the southeastern portion of Yellowstone Park during the past 4,000 years.

\section{Acknowledgments}

We wish to thank $\mathrm{Dr}$. Robert Smith for coring Yellowstone Lake and Dr. Brian Shero for obtaining samples for us. This study was supported by a grant from the Northern Rocky Mountain Cooperative Park Study Program. 


\section{Literature Cited}

Baker, Richard G. 1976. Late quaternary vegetation history of the Yellowstone Lake Basin, Wyoming. Geol. Survey Prof. Pap. 729-E. 48 pp.

Despain, Don G. 1973. Major vegetation zones of Yellows tone National Park. Information Paper No. 19, Yellowstone National Park, National Park Service, U.S. Department of the Interior. $3 p$.

Faegri, Junt, and Iversen, John. 1950. Textbook of modern pollen analysis. Copenhagen, Ejnar Munksgaard. 168 pp.

Mosimann, James. E. 1965. Statistical Methods for the Pollen Analyst:

Multinomial and negative multinomial techniques. In $B$. Kummel and $D$.

Raup (eds.), Handbook of paleontological techniques, W.H. Freeman and Co., San Francisco, California. pp. 636-673.

Shero, Brian R. 1977. An interpretation of temporal and spatial variations in the abundance of diatom taxa in sediments from Yellowstone Lake, Wyoming. Ph.D. Thesis. University of Wyoming, Laramie.

Tauber, H. 1967. Differential pollen dispersion and filtration. In E.J. Cushing and H.E. Wright (eds.), Quaternary Paleoecology, Yale Press, New Haven, Conn. 
University of Wyoming National Park Service Rēedreth Center Annual Report, Vol. 2 [1978], Art. 19
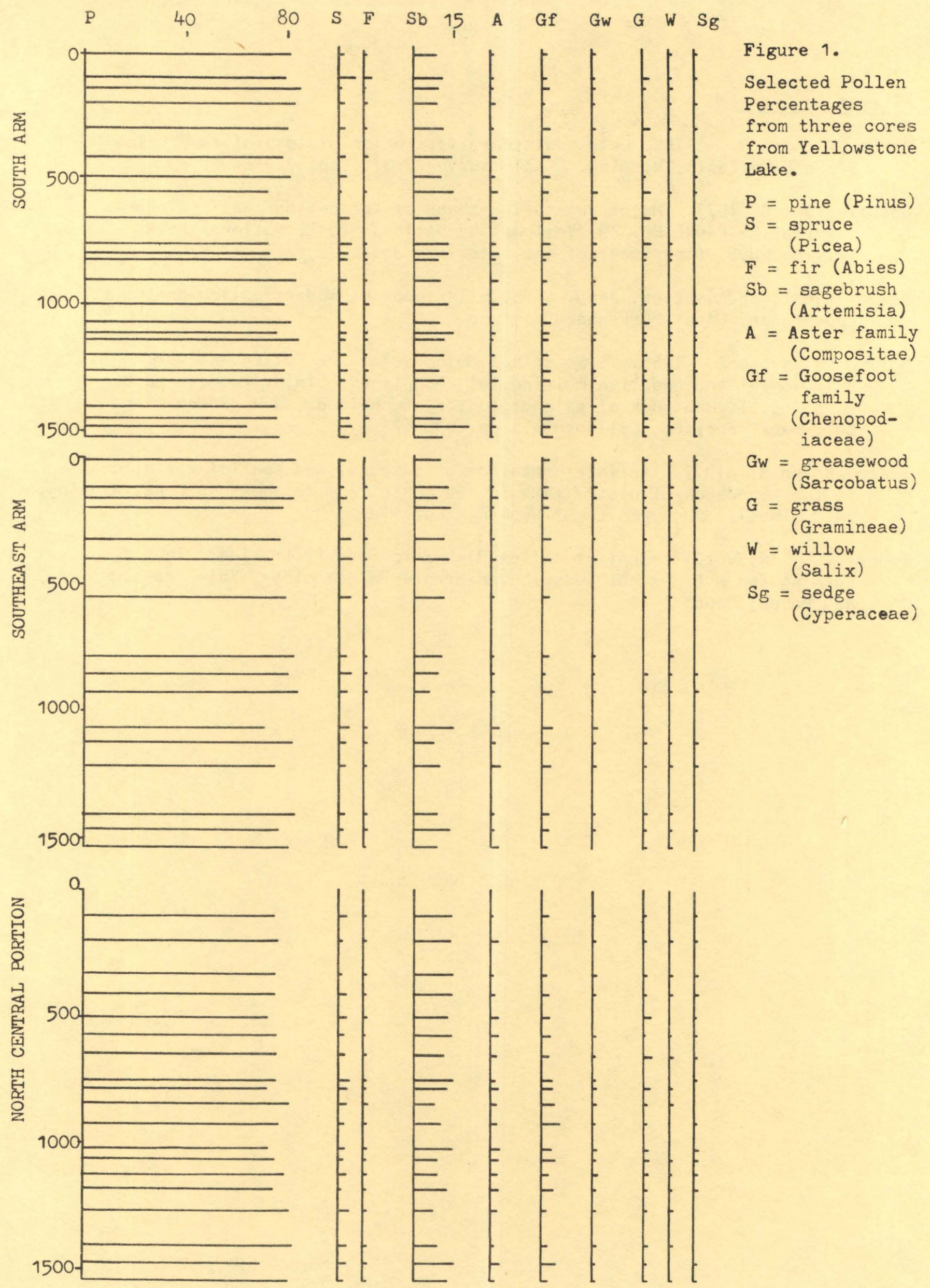
Frison and Beiswenger: Vegetational History of Yellowstone Park as Determined by Pollen
$-91-$

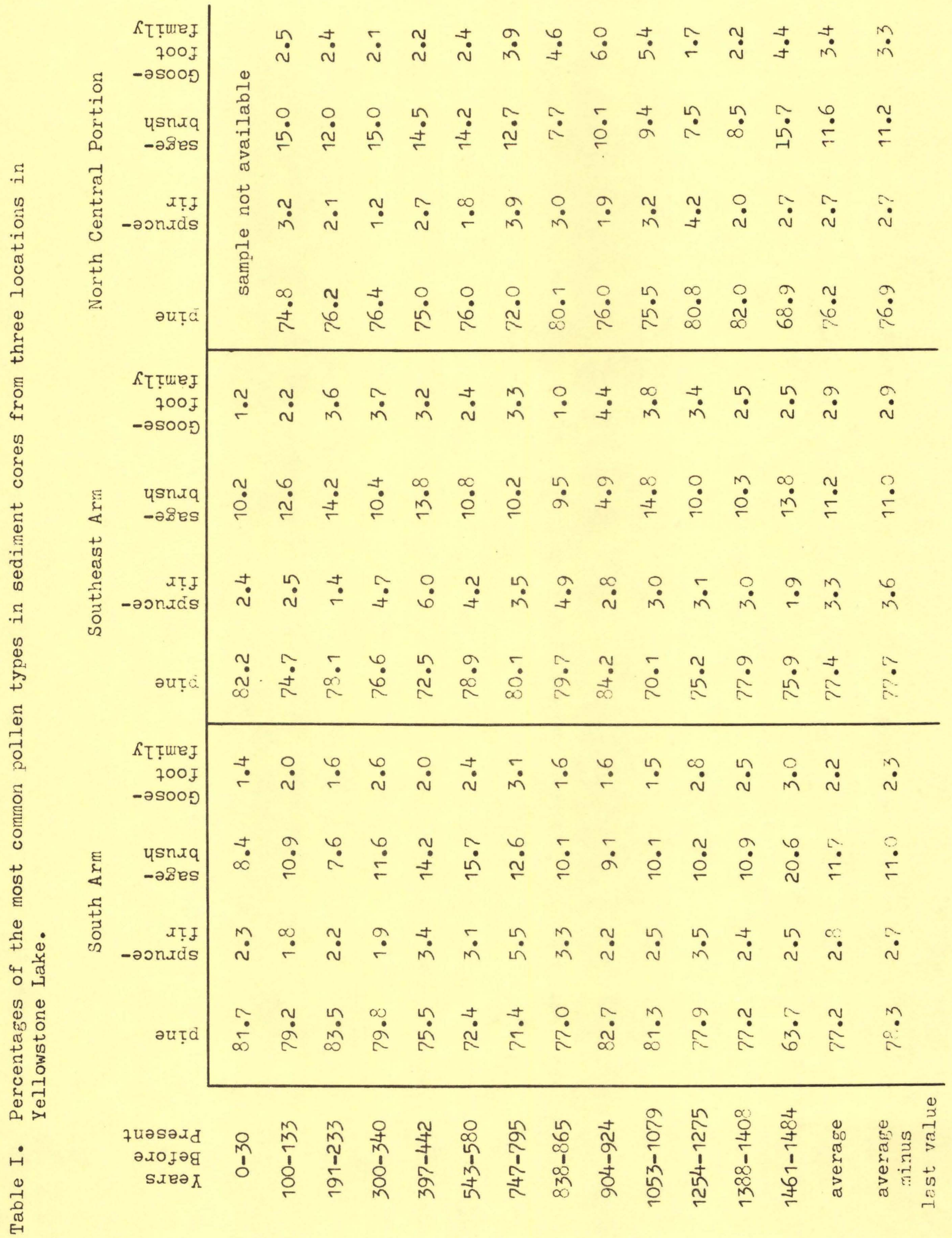

